\title{
Hubungan Faktor Lingkungan Fisik dan Sosial Ekonomi Keluarga Terhadap Kejadian Pneumonia Pada Balita di Wilayah Kerja Puskesmas Tahtul Yaman Kota Jambi
}

\author{
Suryati ${ }^{1 *}$, Nyimas Natasha ${ }^{2}$, Nur Id'ys ${ }^{2}$ \\ ${ }^{1}$ Akademi Keperawatan Telanai Bakti Jambir \\ ${ }^{2}$ Program Studi Ilmu Keperawatan Universitas Jambi \\ *e-mail: suryatifrd@gmail.com
}

\begin{abstract}
ABSTRAK
Pneumonia pada anak termasuk salah satu penyebab kematian tertinggi di dunia yaitu sekitar 20 persen atau sekitar 1,5 juta balita tiap tahunnya meninggal karena penyakit tersebut. Tiap tahun diperkirakan ada 11-20 juta anak di dunia dirawat di rumah sakit karena pneumonia. Di Indonesia pneumonia merupakan penyebab kematian 13,2 persen balita dan penyebab kematian 12,7 persen anak. Tujuan penelitian ini untuk mengetahui hubungan faktor lingkungan fisik dan sosial ekonomi keluarga dengan kejadian Pneumonia pada balita di Wilayah kerja Puskesmas Tahtul Yaman Kota Jambi. Penelitian ini merupakan penelitian case control. Diperoleh 35 ibu yang memiliki balita menderita pneumonia sebagai case (kasus) dan 35 ibu yang memiliki balita tidak menderita pneumonia sebagai control (kontrol) sehingga total sampel berjumlah 70 responden. Proses penelitian dilakukan pada bulan November 2016. Data dianalisis secara univariat dan bivariat dengan uji statistik chi square. Hasil analisa univariat menunjukkan bahwa balita penderita pneumonia sebagian besar berumur 12-23 sebanyak 57,1\%, dan penderita pneumonia sebagian besar berjenis kelamin laki-laki sebanyak 74,3\%. Lingkungan fisik penderita pneumonia umumnya yang kurang baik 68,6\%, dan lingkungan fisik yang baik $31,4 \%$, hasil tingkat sosial ekonomi umumnya tergolong tinggi 54,3\%. Terdapat hubungan antara faktor lingkungan fisik pada balita, dengan $\mathrm{p}$-value $=0,017$ dan $\mathrm{OR}=3,692$ dan faktor sosial ekonomi keluarga dengan $\mathrm{p}$-value $=0,009$ dan OR= 5,053 dengan kejadian pneumonia. Terdapat hubungan antara faktor lingkungan fisik dan sosial ekonomi keluarga dengan kejadian pneumonia pada balita.
\end{abstract}

Kata kunci : Faktor lingkungan fisik; Kejadian pneumonia; Sosial ekonomi keluarga.

\begin{abstract}
Pneumonia in children including one cause of death in the world that is around 20 percent, or about 1.5 million children under five die each year from the disease. Each year there are an estimated 11-20 million children in the world were hospitalized because of pneumonia. In Indonesia, pneumonia is the leading cause of death of 13.2 percent of children under five and 12.7 percent the cause of death of children. The purpose of this study to determine the relationship between the physical environment and socio-economic families with the incidence of pneumonia in children under five in Public Health Center Tahtul Yaman Jambi City period 2015. This study is a case-control study. Retrieved 35 mothers who have children suffering from pneumonia as a case (case) and 35 mothers who have children do not suffer from pneumonia as control (control) so that the total sample of 70 respondents. The research took place in November 2016. Data was analyzed by univariate and bivariate statistical test Chi Square. Results of univariate analysis showed that patients with pneumonia mostly toddlers aged $12-23$ as much as $57.1 \%$, and pneumonia mostly male sex as much as $74.3 \%$. The physical environment pneumonia generally unfavorable $68.6 \%$, and a good physical environment $31.4 \%$, the results of socioeconomic level are generally relatively high $54.3 \%$. There is a relationship between physical environmental factors in infants, with a p-value $=0.017$ and $\mathrm{OR}=3.692$ and socio-economic factors with $\mathrm{p}$-value $=$ 0.009 and $\mathrm{OR}=5.053$ with pneumonia. There is a relationship between physical environmental factors and socioeconomic families with the incidence of pneumonia in infants.
\end{abstract}

Key words : Physical environmental factors; Socioeconomic of family; The incidence of pneumonia.

\section{Pendahuluan}

Pneumonia pada balita adalah penyakit infeksi yang menyerang paru-paru yang ditandai dengan batuk disertai napas cepat dan atau napas sesak pada anak usia balita (0-5 tahun). Penyakit ini disebabkan oleh infeksi pneumokokus. Bakteri pneumokokus sering menyerang bayi dan anak-anak di bawah usia 2 tahun (Pudiastuti, 2011).

Tiap tahun diperkirakan ada 11-20 juta anak di dunia dirawat di rumah sakit karena pneumonia. Di Indonesia pneumonia merupakan penyebab kematian 13,2 persen balita dan penyebab kematian 12,7 persen anak (Kemenkes RI, 2012). Berdasarkan kelompok umur 
penduduk, Period prevalence pneumonia yang tinggi terjadi pada kelompok umur 1-4 tahun, kemudian mulai meningkat pada umur 45-54 tahun dan terus meninggi pada kelompok umur berikutnya. Pneumonia balita lebih banyak dialami pada kelompok penduduk dengan kuintil indeks kepemilikan terbawah (27,4\%).Period prevalence dan prevalensi tahun 2013 sebesar 1,8 persen dan 4,5 persen. Lima provinsi yang mempunyai insiden dan prevalensi pneumonia tertinggi untuk semua umur adalah Nusa Tenggara Timur (4,6\% dan $10,3 \%)$, Papua $(2,6 \%$ dan $8,2 \%)$, Sulawesi Tengah (2,3\% dan 5,7\%), Sulawesi Barat $(3,1 \%$ dan $6,1 \%)$, dan Sulawesi Selatan (2,4\% dan 4,8\%) (Manurung, 2013).

Penyebab pneumonia adalah bakteri, virus, mikoplasma, jamur dan protozoa (Wijayaningsih, 2013). Komplikasi yang dapat terjadi apabila klien pneumonia tidak tertangani secara cepat dan tepat adalah empiema, emfisema, atelektasis, otitis media akut dan meningitis. Pencegahan pneumonia dilaksanakan melalui upaya peningkatan kesehatan seperti imunisasi, perbaikan gizi dan perbaikan lingkungan pemukiman. Peningkatan pemerataan cakupan kualitas pelayanan kesehatan juga akan menekan morbiditas dan mortalitas pneumonia. Peranan masyarakat sangat menentukan keberhasilan upaya penanggulangan pneumonia (Maryunani, 2010). Terpenting adalah masyarakat memahami cara mendeteksi dini dan cara mendapatkan pertolongan pertama (care seeking) (Centiany, 2013).

Hasil penelitian yang dilakukan Centiany (2013) dengan judul "Hubungan antara Faktor Lingkungan Fisik Rumah dengan Kejadian Infeksi Saluran Pernapasan (ISPA) pada Balita di Kelurahan Malalayang 1 Kota Manado. Menunjukkan bahwa ada hubungan antara suhu ruangan rumah, kebiasaan anggota keluarga yang merokok, jenis obat anti nyamuk, jenis lantai rumah, kepadatan hunian kamar tidur dengan kejadian Ispa pada balita (Aji, 2008). Hasil penelitian yang dilakukan Aji (2008) menunjukkan ada hubungan yang bermakna antara jenis lantai, kondisi dinding rumah, luas ventilasi rumah, tingkat kepadatan hunian, tingkat kelembaban, penggunaan jenis bahan bakar kayu, kebiasaan anggota keluarga responden yang merokok dengan kejadian pneumonia (Dinkes Provinsi Jambi, 2014).

Tahun 2014 di Provinsi Jambi, Cakupan penemuan pneumonia pada balita sebesar 4.286 kasus atau cakupan $14,54 \%$. Berdasarkan data Dinas Kesehatan Provinsi Jambi tahun 2014 menunjukkan bahwa jumlah pneumonia pada balita sebesar $14,54 \%$. Jumlah kasus pneumonia pada balita tertinggi di Kabupaten Bungo sebesar 27,7\%. Sedangkan jumlah kasus pneumonia pada balita di Kota Jambi menduduki peringkat ketiga sebesar $20 \% .{ }^{8}$ Berdasarkan data Dinas Kesehatan Kota Jambi tahun 2015 menunjukkan bahwa dari 60.102 balita di Kota Jambi dengan jumlah perkiraan pneumonia sebanyak 1.893 balita sedangkan jumlah balita yang menderita pneumonia sebanyak 2.239 balita sehingga diperoleh rata-rata persentase balita yang menderita pneumonia berbanding dengan jumlah perkiraan balita yang menderita pneumonia adalah terbanyak $118,27 \%$. Jumlah balita yang menderita pneumonia terbanyak adalah di Puskesmas
Tahtul Yaman sebanyak 183 balita dari perkiraan balita yang menderita sebanyak 45 balita.

Berdasarkan survei awal penelitian yang dilakukan di Wilayah Kerja Puskesmas Tahtul Yaman Kota Jambi sebanyak10 rumah. 6 rumah pangung dan 4 rumah permanen. Dari 7 rumah penduduk terlihat dapur menyatu dengan ruang keluarga, dan ventilasi di dapur tidak memenuhi standar. Kemudian 3 rumah penduduk terlihat dapur tidak menyatu dengan ruang keluarga, kemudian memiliki ventilasi dan sebagian besar didapur rumah warga tidak mempunyai cerobong asap atau jendela. Dalam satu rumah dengan kondisi yang sempit dihuni beberapa KK. Terdapat anggota keluarga yang merokok dalam rumah tersebut, sebagian rumah warga dikelilingi rawa dan terletak di dekat pabrik karet sehingga hasil pembakaran dari pengolahan pabrik tersebut sampai di pemukiman penduduk. Kepala keluarga mayoritas bekerja sebagai bekerja sebagai nelayan dan buruh yang hasilnya hanyasekedar cukupuntuk mencukupi kehidupan sehari-hari, kemudian sebagian istri hanya sebagai ibu rumah.Polusi udara dalam ruangan yang disebabkan oleh memasak, di rumah dengan jumlah anggota melebihi kapasitas fisik rumah, debu dan perilaku keluarga merokok di dalam rumah merupakan faktor lingkungan yang meningkatkan risiko kerentanan anak untuk mengalami pneumonia. Penelitian ini bertujuan hubungan faktor lingkungan fisik dan sosial ekonomi keluarga dengan kejadian pneumonia pada balita di Wilayah Kerja Puskesmas Tahtul Yaman Kota Jambi.

\section{Metode Penelitian}

Sampel pada penelitian ini menggunakan perbandingan case control (1:1) yang diambil dengan teknik random sampling yaitu pengambilan sampel secara acak sederhana ibu yang memiliki balita menderita pneumonia,sehingga diperolehyang $35 \mathrm{ibu}$ yang memiliki balita menderita pneumonia sebagaicase (kasus) dan $35 \mathrm{ibu}$ yang memiliki balita tidak menderita pneumonia sebagaicontrol (kontrol) sehingga total sampelberjumlah 70 responden.

Proses matching antara kasus dengan kontrol dilakukan berdasarkan lokasi tempat tinggal kasus dan kontrol berada. Jumlah kasus dan kontrol disamakan proporsinya sesuai wilayah (kelurahan).

Pengumpulan data dilakukan melalui pengisian kuesioner oleh responden terkait data tentang sosial ekonomi keluarga, lembar observasi terkait dengan faktor lingkungan serta kejadian pneumonia diambild ari data sekunder dari Puskesmas Tahtul Yaman Kota Jambi. Untuk melihat hubungan antara variabel independent (faktor lingkungan fisik dan sosial ekonomi keluarga) dan dependent kejadian pneumonia pada balita) menggunakan analisis secara bivariat. Analisisnya menggunakan uji statistik dengan menggunakan analisa Chi-Squere dengan menggunakan analisa komputerisasi. Untuk melihat batas kemaknaan $\alpha 0,05$ 


\section{Hasil dan Pembahasan}

\subsection{Gambaran Faktor Lingkungan Fisik Penderita Pneumonia Pada Balita di Wilayah Kerja Puskesmas Tahtul Yaman Kota Jambi}

Hasil penelitian pada faktor lingkungan fisik penderita pneumonia pada balita di Wilayah Kerja Puskesmas Tahtul Yaman Kota Jambi menunjukkan bahwa sebanyak 35 responden kasus dengan lingkungan fisik yang kurang baik sebanyak 24 responden $(68,8 \%)$ dan yang memiliki lingkungan fisik baik sebanyak 11 responden $(31,4 \%)$, sedangkan dari 35 responden kontrol dengan lingkungan fisik kurang baik sebanyak 13 responden $(37,1 \%)$ dan yang memiliki lingkungan fisik baik sebanyak 22 responden $(62,9 \%)$.

Hasil penelitian menunjukkan bahwa lingkungan fisik yang sudah baik dalam mencegah terjadinya resiko kejadian pneumonia pada balita diantaranya kualitas udara dimana sebagian besar responden memiliki rumah yang sehat dengan kriteria sinar matahari dapat masuk ke dalam rumah melalui jendela dan hasil penelitian sebanyak $(74,3 \%)$ responden. Hal ini dikarenakan masih banyak responden yang merupakan ibu rumah tangga sehingga banyak aktivitas yang masih dilakukan di rumah seperti membuka jendela pada pagi hari agar sinar matahari dapat masuk dan terjadinya pertukarann udara pagi yang segar melalui jendela.

Faktor lingkungan yang mempengaruhi status kesehatan seseorang itu, salah satunya dapat berasal dari lingkungan pemukiman (lingkungan fisik rumah). Lingkungan yang sehat dapat dikatakan sehat bila sudah memenuhi syarat-syarat lingkungan yang sehat. Lingkungan fisik rumah yang tidak memenuhi syarat kesehatan dan perilaku hidup yang tidak sehat, dapat mendukung terjadinya penularan penyakit dan gangguan kesehatan, salah satunya penyakit pneumonia pada balita (Adnani, 2011)

Kriteria rumah sehat juga ditemukan dengan seluruh responden ruangan dalam rumah tidak berdebu karena lantai rumah sebagian besar dari papan yang dialasi alas tikar atau karpet serta ada juga beberapa rumah yang lantainya sudah dikeramik. Lantai dari tanah yang banyak mengandung unsur debu tidak ditemukan karena rumah-rumah penduduk banyak yang panggung, serta meskipun tidak panggung lantai rumah mereka tidak lagi lantai tanah melainkan sudah keramik atau lantai semen. Lantai kedap air adalah syarat bagi rumah sehat. Bahannya bisa beragam: ubin, semen, kayu, atau keramik. Lantai yang berdebu atau becek selain tidak nyaman juga bisa menjadi sarang penyakit.

Selain itu, sebagian besar responden juga memiliki rumah yang jauh dari jalan raya sehingga tidak terpapar oleh debu dari jalanan. Selain itu, akses jalan disana tidak lagi tanah karena jalan raya sudah diaspal sedangkan jalan yang melewati wilayah ini bukanlah jalan akses utama tapi sudah diaspal. Akses jalan penghubung antar rumah seperti lorong-lorong jga sudah banyak yang dilakukan pengerasan dengan semen sehingga tidak menimbulkan paparan debu jika kendaraan melintas, tidak seperti jalan yang masih
Puskesmas Tahtul Yaman Kota Jambi (Suryati, Natasha, N, Id'ys, N)

tekstur tanah. Baiknya kondisi akses jalan ini karena adanya program pemerintah setempat dalam menciptakan infrastruktur pembangunan di daerah pemukiman masyarakat menjadi lebih baik.

Hasil penelitian juga menunjukkan masih banyak responden yang memiliki lingkungan fisik rumah yang kurang baik dimana belum memenuhi standar rumah sehat. Hal ini terlihat masih ada sebagian responden yang menggunakan bahan bakar masak yang menimbulkan asap atau polusi udara di rumah dapat tercemar seperti penggunaan kayu bakar untuk memasak yaitu $60 \%$. Terlebih masih banyak ditemukan rumah dimana dapur menyatu dengan ruang keluarga yaitu 91,4\% serta kurangnya pemasangan cerobong asap di atas dapur tempat keluarnya asap hasil pembakaran saat memasak karena masih banyak yang hanya mengandalkan ventilasi dapur saja berdasarkan penelitian yang memilih cerobong asap atau jendela yaitu $40,0 \%$.

Jenis bahan bakar yang digunakan untuk kegiatan memasak sehari-hari saling berkaitan erat dengan kualitas udara di dalam rumah. Asap yang dihasilkan dari hasil pembakaran kayu akan lebih banyak apabila dibandingkan dengan asap hasil pembakaran gas. Banyaknya asap yang dihasilkan dari pembakaran di ruang dapur, apabila asap tersebut tidak musah keluar maka akan mengganggu sistem pernapasan seseorang terutama balita yang berada di ruangan dapur tersebut. Dengan demikian seseorang terutama balita akan menderita sesak napas. Sehingga jenis bahan bakar tertentu sangat berhubungan dengan kejadian pneumonia pada anak balita. Ruang dapar merupakan sumber pencemaran udara dalam ruang rumah. Selama memasak terjadi emisi berbagai bahan pencemar, baik berasal dari pembakaran tidak sempurna dari bahan bakar biomossa (kayi, jerami, batu bara) maupun pengupan dari bahan makanan yang dimasak. Kegiatan memasak dilakukan secara terus menerus (setiap hari) dalam waktu yang cukup lama sehingga asap dari dapaur akan mencemari seluruh ruangan, termasuk kamar tidur tempat anggota keluarga lebih banyak menghabiskan waktunya pada malam hari (Putriani, 2014).

Selain itu, adanya kebiasaan merokok dari anggota keluarga menyebabkan udara dari dalam rumah tercemar atau terpapar oleh polusi asap rokok sehingga dapat mengganggu kualitas udara di dalam rumah. Hal ini terlihat sebagian besar anggota keluarga laki-laki dewasa sebagian besar perokok dan wanitawanita yang sudah tua juga banyak yang menjadi perokok aktif. Paparan asap rokok di dalam rumah semakin lama akan menurunkan kualitas udara di dalam rumah sehingga paparan asap rokok dapat mempengaruhi kondisi kesehatan balita yang ada di rumah tersebut.

Asap rokok mengandung zat beracun yang berbahaya bagi kesehatan terutama pada balita. Beberapa bahan kimia asap rokok yang terkandung didalamnya yaitu nikotin, gas karbon monoksida, nitrogen oksida, hidrogen sianida, ammonia, acrrolein, acetilen, benzoldehide, urethane, methamol, conmarin, 4-ethyl cathacol, orteresor peyline dan lain-lain. Berbaagai bahan kimia tersebut dapat merangsang silia 
yaitu hulu-bulu halus yang terdapat pada permukaan saluran napas, sehingga sekret mukus meningkat menjadi $30-50 \%$. Hal ini akan mengakibatkan silis akan mengalami kerusakan dan mengakibatkan menurunnya fungsi ventilasi paru. Asap rokok dapat mengakibatkan menurunnya imun. Kerusakan dari saluran napas disertai dengan menurunnya imunitas tubuh dapat menyebabkan mudahnya terjadi infeksi pada saluran pernapasan (Arsindo, 2014).

Responden yang memiliki jarak lokasi rumah dengan jalan raya 3-5 m sebanyak $60,0 \%$ hal ini dapat memungkinkan untuk terpapar oleh asap kendaraan bermotor, debu jalanan serta kabut asap. Sumber polusi yang utama berasal dari transportasi hampir $60 \%$ dihasilkan dari karbon monoksida dan $15 \%$ terdiri dari hidrokarbon. Partikel debu dapat menyebabkan gangguan sistem pernapasan, iritasi mata, alaergi, bronchitis khronis. Kabut asap terjadi karena adanya pembakaran baik itu pembakaran sampah maupun pembakaran lahan atau hutan (Arsindo, 2014).

Besarnya pengaruh lingkungan fisik rumah terhadap derajat kesehatan anggota keluarga terutama balita terhadap kejadian pneumonia, maka perlu upaya penataan rumah yang memenuhi kriteria rumah sehat baik dari segi lokasi dapur, penggunaan bahan bakar memasak, pencegahan kebiasaan merokok di dalam rumah, kualitas ventilasi dan jendela yang memungkinkan pertukaran udara yang sehat serta masuknya sinar matahari, kekuatan dna kebersihan lantai serta dinding rumah, sanita di sekitar lingkungan rumah serta kualitas udara di sekitar lingkungan rumah yang bebas dari paparan pencemaran maupun polusi udara. Oleh sebab itu, perlunya upaya tenaga kesehatan untuk emmberikan penuluhan tentang lingkungan fisik dan sanitasi di sekitar lingkungan rumah yang memenuhi standar rumah sehat agar lingkungan fisik rumah dapat mendukung peningkatan kesehatan balita serta memperkecil risiko adanya paparan lingkungan fisik yang kurang baik yang menyebabkan kejadian pneumonia pada balita.

\subsection{Gambaran Sosial Ekonomi Keluarga Penderita Pneumonia Pada Balita di Wilayah Kerja Puskesmas Tahtul Yaman Kota Jambi}

Hasil penelitian pada faktor sosial ekonomi keluarga penderita pneumonia pada balita di Wilayah Kerja Puskesmas Tahtul Yaman Kota Jambi menunjukkan menunjukkan bahwa sebanyak 35 responden kasus dengan faktor sosial ekonomi keluarga rendah sebanyak 16 responden $(45,7 \%)$ dan faktor sosial ekonomi keluarga yang yang tinggi sebanyak 19 responden $(54,3 \%)$, sedangkan dari 35 responden kontrol dengan faktor sosial ekonomi keluarga rendah sebanyak 5 responden $(14,3 \%)$ dan faktor sosial ekonomi keluarga tinggi sebanyak 30 responden $(85,7 \%)$.

Sosial ekonomi adalah kedudukan atau posisi seseorang dalam kelompok masyarakat yang ditentukan oleh jenis aktivitas ekonomi, pendidikan serta pendapatan (Disnaketrans, 2016). Aspek ekonomi seperti pendapatan merupakan syarat utama untuk dapat menikmati fasilitas kesehatan dalam upaya meningkatkan kesehatan masyarakat. Kemiskinan merupakan salah satu faktor yang menghambat dalam pembangunan ekonomi dan kesehatan. Penduduk miskin memiliki beban penyakit yang tinggi karena terbatasnya akses terhadap air bersih dan sanitasi serta kecukupan gizi. Selain itu biaya yang cukup tinggi untuk mendapatkan pelayanan kesehatan membuat penduduk miskin lebih memilih pengobatan alternatif serta rendahnya pendidikan membuat keterbatasan pengetahuan dalam menghadapi suatu penyakit. Komunikasi kesehatan adalah suatu cara yang dilakukan pelayanan kesehatan untuk mengajak penduduk miskin untuk merubah perilaku dan memperbaiki kesehatan mereka (Manurung, 2010).

Tingkat ekonomi seseorang berhubungan erat dengan berbagai masalah kesehatan. Orang dengan tingkat ekonomi rendah akan lebih berkosentrasi terhadap pemenuhan kebutuhan dasar yang menunjang kehidupannya dan kehidupan keluarganya. Sebaliknya orang dengan tingkat ekonomi tinggi akan mempunyaikesempatan lebih besar dalam menempuh pendidikan dimana orang dengan tingkat ekonomi tinggi akan lebih mudah menerima informasi sehingga makin banyak pula pengetahuan yang dimiliki sehingga makin banyak pula pengetahuan yang dimiliki sehingga akan memperhatikan kesehatan diri dan keluarga (Centiany, 2013).

Dalam hal pemenuhan makanan, meskipun dengan ekonomi yang rendah tetap mampu menyediakan makanan yang sehat dengan lebih memetingkan kandungan pada bahan makanan serta cara pengolahan makanan yang akan disajikan pada anggota keluarga. Begitu juga dengan akses pelayanan kesehatan, meskipun dengan ekonomi rendah, selain jaminan adanya kesehatan untuk ekonomi rendah, sebaiknya seluruh anggota keluarga diikutsertakan dalam program BPJS agar jika sewaktu-waktu membutuhkan dapat meringankan beban dalam membiayai perawatan kesehatan jika ada yang sakit.

Pendapatan keluarga selain dipergunakan untuk memenuhi kebutuhan sandang, pangan, dan papan bagi keluarganya, juga diperlukan untuk biaya dalam pemenuhan kesehatan. Dengan pendapatan keluarga yang tinggi, maka biaya yang dikeluarkan untuk memperoleh pelayanan kesehatan akan terjangkau seperti pemenuhan kebutuhan gizi bagi anggota keluarga, biaya pengobatan, serta memperoleh tempat layak huni yang memenuhi syarat kesehatan.

Kemampuan ekonomi seseorang akan berpengaruh pada pola pemenuhan kebutuhan rumah tangganya termasuk kemampuan pemenuhan kesehatan bagi balitanya. Oleh sebab itu, perlunya peningkatan gizi makanana untuk anggota keluarga dengan mempertimbangkan kandungan gizi bahan makanan yang disajikan, menggunakan akses BPJS sebagai penjamin dalam mendapatkan pelayanan kesehatan, serta mengupayakan sumber daya yang ada serta keterampilan dalam mendongkrak ekonomi keluarga menjadi lebih baik. Perlunya peran tenaga kesehatan dengan memberikan pentingnya keikutsertaan program BPJS, serta penyuluhan tentang pentingnya pemenuhan kebutuhan makanan yang bergizi bagi anggota 
keluarganya dengan membeli bahan makanan yang tidak mahal tetapi mengandung gizi yang tinggi.

\subsection{Hubungan Faktor Lingkungan Fisik Dengan Kejadian Pneumonia Pada Balita di Wilayah Kerja Puskesmas Tahtul Yaman Kota Jambi}

Dari hasil analisis bivariat tentang hubungan antara faktor lingkungan fisik dengan kejadian pneumonia pada balita di Wilayah Kerja Puskesmas Tahtul Yaman Kota Jambi, dapat dilihat pada tabel 1.

Tabel 1. Hubungan antara faktor lingkungan fisik dengan kejadian pneumonia pada balita di wilayah kerja puskesmas Tahtul Yaman Kota Jambi

\begin{tabular}{|c|c|c|c|c|c|c|c|c|c|}
\hline \multirow{3}{*}{ No } & \multirow{3}{*}{$\begin{array}{l}\text { Lingkungan } \\
\text { Fisik }\end{array}$} & \multicolumn{4}{|c|}{ Kejadian Pneumonia } & \multirow{2}{*}{\multicolumn{2}{|c|}{-Total }} & \multirow{3}{*}{ p-value } & \multirow{3}{*}{ OR } \\
\hline & & \multicolumn{2}{|c|}{ Kasus } & \multicolumn{2}{|c|}{ kontrol } & & & & \\
\hline & & $\sum$ & $\%$ & $\sum$ & $\%$ & $\sum$ & $\%$ & & \\
\hline 1 & Kurang Baik & 24 & 68,6 & 13 & 37,1 & 37 & 52,9 & 0,017 & 3,692 \\
\hline 2 & Baik & 11 & 31,4 & 22 & 62,9 & 33 & 47,1 & & \\
\hline \multicolumn{2}{|c|}{ Total } & 35 & 100,0 & 35 & 100,0 & 70 & 100,0 & & \\
\hline
\end{tabular}

Tabel 2. Hubungan antara faktor sosial ekonomi dengan kejadian pneumonia pada balita di wilayah kerja puskesmas Tahtul Yaman Kota Jambi

\begin{tabular}{|c|c|c|c|c|c|c|c|c|c|}
\hline \multirow{3}{*}{ No } & \multirow{3}{*}{$\begin{array}{c}\text { Sosial Ekonomi } \\
\text { Keluarga }\end{array}$} & \multicolumn{4}{|c|}{ Kejadian Pneumonia } & \multirow{2}{*}{\multicolumn{2}{|c|}{ Total }} & \multirow{3}{*}{ p-value } & \multirow{3}{*}{ OR } \\
\hline & & \multicolumn{2}{|c|}{ kasus } & \multicolumn{2}{|c|}{ Kontrol } & & & & \\
\hline & & $\sum$ & $\%$ & $\sum$ & $\%$ & & $\%$ & & \\
\hline 1 & Rendah & 16 & 45,7 & 5 & 14,3 & 21 & 30,0 & 0,009 & 5,053 \\
\hline \multirow[t]{2}{*}{2} & Tinggi & 19 & 54,3 & 30 & 85,7 & 49 & 70,0 & & \\
\hline & Total & 35 & 100,0 & 35 & 100,0 & 70 & 100,0 & & \\
\hline
\end{tabular}

Berdasarkan Tabel 1, diperoleh gambaran bahwa dari 35 responden kasus sebanyak 24 responden $(68,6 \%)$ memiliki lingkungan fisik yang kurang baik dan hanya 11 responden $(31,4 \%)$ memiliki lingkungan fisik yang baik. Sedangkan dari 35 responden dengan balita kontrol sebanyak 22 responden $(62,9 \%)$ memiliki lingkungan fisik yang baik dan hanya 13 responden $(37,1 \%)$ memiliki lingkungan fisik yang kurang baik.

Untuk mengetahui hubungan antara faktor lingkungan fisik dengan kejadian pneumonia pada balita di Wilayah Kerja Puskesmas Tahtul Yaman Kota Jambi, dipergunakan uji analisis Chi-Square dengan tingkat kepercayaan $95 \%(\alpha=0,05)$, maka diperoleh $\mathrm{p}$ value $(0,017)<\alpha(0,05)$, maka ada hubungan antara faktor lingkungan fisik dengan kejadian pneumonia pada balita. Dari analisis juga diketahui nilai odds ratio $(O R)=3,692$, artinya balita dengan lingkungan fisik yang kurang baik berisiko mempunyai peluang 3,7 kali untuk mengalami kejadian pneumonia dibandingkan dengan balita dengan lingkungan fisik yang baik.

Dari hasil penelitian ditemukan bahwa dari 35 responden kasus sebanyak 24 responden $(68,6 \%)$ memiliki lingkungan fisik yang kurang baik dan hanya 11 responden $(31,4 \%)$ memiliki lingkungan fisik yang baik. Sedangkan dari 35 responden kontrol sebanyak 22 responden $(62,9 \%)$ memiliki lingkungan fisik yang baik dan hanya 13 responden $(37,1 \%)$ memiliki lingkungan fisik yang kurang baik.

Hasil penelitian menggunakan uji analisis $\mathrm{Chi}$ Square dengan tingkat kepercayaan 95\% $(\alpha=0,05)$ diperoleh p-value $(0,017)<\alpha(0,05)$, hal ini berarti adanya hubungan yang signifikan antara faktor lingkungan fisik dengan kejadian pneumonia pada balita di Wilayah Kerja Puskesmas Tahtul Yaman Kota Jambi.
Hasil penelitian di atas menunjukkan bahwa semakin baik lingkungan fisik rumah yang ditempati balita, maka akan semakin kecil resiko kejadian penyakit pneumonia. Seblaiknya, semakin kurang baik lingkungan fisik rumah yang ditempati balita, maka akan semakin besar resiko kejadian penyakit pneumonia. Hal ini juga diketahui dari nilai odds ratio $(\mathrm{OR})=3,692$, artinya balita dengan lingkungan fisik yang kurang baik berisiko mempunyai peluang 3,7 kali untuk mengalami kejadian pneumonia dibandingkan dengan balita dengan lingkungan fisik yang baik.

Penelitian ini sejalan dengan penelitian Centiany pada tahun 2013 dengan judul "Hubungan antara Faktor Lingkungan Fisik Rumah dengan Kejadian Infeksi Saluran Pernapasan (ISPA) pada Balita di Kelurahan Malalayang 1 Kota Manado. Hasil penelitian tersebut menunjukkan bahwa ada hubungan antara, kebiasaan anggota keluarga yang merokok dengan $\mathrm{p}$ value 0,047 , jenis obat anti nyamuk dengan $\mathrm{p}$-value 0,005 , jenis lantai rumahdengan p-value 0,02 , kepadatan hunian kamar tidur dengan p-value 0,072 kejadian Ispa pada balita. ${ }^{6}$ kemudian penelitian Aji pada tahun 2008 dengan judul "Faktor - Faktor Lingkungan Fisik Rumah yang Berhubungan dengan Kejadian Pneumonia pada Anak Balita di Wilayah Kerja Puskesmas Kawunganten Kabupaten Cilacap. Hasil penelitian menunjukkan ada hubungan yang bermakna antara jenis lantai dengan p-value 0,001, kondisi dinding rumah dengan p-value 0,013, luas ventilasi rumah dengan p-value 0,001 , tingkat kepadatan hunian dengan p-value 0,028, tingkat kelembaban dengan p-value 0,019, penggunaan jenis bahan bakar kayu dengan p-valeu 0,011, kebiasaan anggota keluarga responden yang merokok dengan $\mathrm{p}$ value 0,022 kejadian pneumonia. ${ }^{7}$ 
Rumah merupakan salah satu kebutuhan dasar manusia yang berfungsi sebagaitempat tinggal atau hunian dan sarana pembinaan keluarga. Rumah harus sehat dannyaman agar penghuninya dapat melakukan aktivitas sehari-hari dengan aman tanpaadanya resiko/gangguan. Konstruksi rumah dan lingkungan rumah yang tidakmemenuhi syarat kesehatan merupakan faktor risiko penularan berbagai jenis penyakit,khususnya penyakit yang berbasis lingkungan seperti pneumonia.

Angka kejadian pneumonia pada balita yang tinggi seringkali ditemukan di daerah dengan sanitasi hidup yang buruk. Padahal, faktor lingkungan yang baik, adalah salah satu kunci penting dalam mencegah terjadinya penyakit ini. Lingkungan yang kurang bersih, ditambah dengan sistem imun tubuh balita yang belum kuat dengan tambahan berbagai faktor resiko lain seperti kurangnya pemberian ASI dan asupan nutrisi yang buruk, merupakan faktor utama yang menyebabkan bakteri maupun virus penyebab pneumonia menyerang balita.

Faktor yang meningkatkan risiko penularan pneumokokus di antaranya adalah anak tinggal di lingkungi polusi dan lingkungan perokok dan anak tinggal di hunian padat atau lingkungan yang tidak sehat. ${ }^{1}$ Asap rumah tangga yang masih menggunakan kayu bakar juga menjadi salah satu faktor risiko pneumonia. Hal ini dapat diperburuk apabila ventilasi rumah kurang baik dan dapur menyatu dengan ruang keluarga atau kamar (Manurung, 2013).

Selain itu, poluasi udara terutama yang jarak rumahnya dekat dengan jalan, dapat memungkinkan untuk terpapar oleh asap kendaraan bermotor, debu jalanan serta kabut asap. Sumber polusi yang uatama berasal dari transportasi hampir $60 \%$ dihasilkan dari karbon monoksida dan $15 \%$ terdiri dari hidrokarbon. Partikel debu dapat menyebabkan gangguan sistem pernapasan, iritasi mata, alaergi, bronchitis khronis. Kabut asap terjadi karena adanya pembakaran baik itu pembakaran sampah maupun pembakaran lahan atau hutan. ${ }^{17}$ Rumah yang letaknya di pinggiran jalan, Garis Sempadan Bangunan nya ditentukan oleh fungsi serta kelas jalan. Untuk lingkungan pemukiman standardnya ialah berkisar antara 3 sampai dengan $5 \mathrm{~m}$ (Roestanto, 2014). Sedangkan secara umum kriteria pertimbangan pemilihan lokasi dalam pembangunan kawasan industri di Indonesia dimana jarak terhadap permukiman minimal $2 \mathrm{~km}$.

Besarnya pengaruh lingkungan fisik terhadap kejadian pneumonia, maka sebaiknya perlu upaya peningkatan kebersihan baik di dalam rumah maupun sekiatr rumah serta memperhatikan kondisi kesehatan rumah agar dapat memenuhi kriteria rumah sehat sehingga anggota keluarga yang tinggal di dalamnya tidak mudah terserang penyakit akibat lingkungan fisik rumah yang kurang baik.
Puskesmas Tahtul Yaman Kota Jambi (Suryati, Natasha, N, Id'ys, N)

\subsection{Hubungan Faktor Sosial Ekonomi Keluarga Dengan Kejadian Pneumonia Pada Balita di Wilayah Kerja Puskesmas Tahtul Yaman Kota Jambi}

Dari hasil analisis bivariat tentang hubungan antara faktor sosial ekonomi keluarga dengan kejadian pneumonia pada balita di Wilayah Kerja Puskesmas Tahtul Yaman Kota Jambi, dapat digambarkan pada tabel 2. Berdasarkan tabel 2, diperoleh gambaran bahwa dari 35 responden kasus sebanyak 16 responden $(45,7 \%)$ memiliki sosial ekonomi keluarga yang rendah dan 19 responden $(54,3 \%)$ memiliki sosial ekonomi keluarga yang tinggi. Sedangkan dari 35 responden kontrol sebanyak 30 responden $(85,7 \%)$ memiliki sosial ekonomi keluarga yang tinggi dan hanya 5 responden $(14,3 \%)$ memiliki sosial ekonomi keluarga yang rendah.

Untuk mengetahui hubungan antara faktor sosial ekonomi keluarga dengan kejadian pneumonia pada balita di Wilayah Kerja Puskesmas Tahtul Yaman Kota Jambi, dipergunakan uji analisis Chi-Square dengan tingkat kepercayaan 95\% $(\alpha=0,05)$, maka diperoleh $\mathrm{p}$ value $(0,009)<\alpha(0,05)$, maka ada hubungan antara faktor sosial ekonomi keluarga dengan kejadian pneumonia pada balita.Dari analisis juga diketahui nilai odds ratio $(\mathrm{OR})=5,053$, artinya balita dengan sosial ekonomi keluarga yang rendah berisiko mempunyai peluang 5 kali untuk mengalami kejadian pneumonia dibandingkan dengan balita dengan sosial ekonomi keluarga yang tinggi.

Hasil penelitian pada gambaran karakteristik pneumonia pada balita di Wilayah Kerja Puskesmas Tahtul Yaman Kota Jambi berdasarkan umur balita ditemukan bahwa dari 35 responden kasus terbanyak usia 12-23 bulan sebanyak 20 responden $(57,1 \%)$ sedangkan dari 35 responden kontrol terbanyak usia 2435 bulan sebanyak 11 responden $(31,4 \%)$. Hasil penelitian tersebut menunjukkan bahwa balita yang mengalami pneumonia mayoritas memiliki usia yang lebih muda dari pada yang tidak menderita pneumonia.

Pneumonia pada balita adalah penyakit infeksi yang menyerang paru-paru yang ditandai dengan batuk disertai napas cepat dan atau napas sesak pada anak usia balita (0-5 tahun). Penyakit ini disebabkan oleh infeksi pneumokokus. Bakteri pneumokokus sering menyerang bayi dan anak-anak di bawah usia 2 tahun. ${ }^{1}$ Bayi dan balita memiliki mekanisme pertahanantubuh yang masih rendah dibanding orang dewasa,sehingga balita masuk ke dalam kelompok yangrawan terhadap infeksi seperti influenza dan pneumonia.Anak-anak berusia 0-24 bulan lebih rentanterhadap penyakit pneumonia dibanding anakanakberusia di atas 2 tahun. Hal ini disebabkan imunitasyang belum sempurna dan saluran pernapasan yangrelatif sempit. Hal ini sesuai dengan hasil penelitian dengan usia penderita pneumonia sebanyak $(41,4 \%)$ berusia $12-23$ bulan.

Gambaran karakteristik responden berdasarkan jenis kelamin balita di Wilayah kerja Puskesmas Tahtul Yaman Kota Jambi menunjukkan bahwa dari 35 responden kasus terbanyak balita laki-laki sebanyak 26 responden $(74,3,0 \%)$ dan yang terendah balita perempuan sebanyak 9 responden $(25,7 \%)$, sedangkan 
dari 35 responden kontrol terbanyak balita perempuan sebanyak 20 responden $(57,1 \%)$ dan yang terendah balita laki-laki sebanyak 15 responden $(42,9 \%)$.

Hal ini sesuai dengan teori dan anak laki-laki adalah faktor risiko yang mempengaruhi kesakitan pneumonia. Hal ini disebabkan diameter saluran pernapasan anak laki-laki lebih kecil dibandingkan dengan anak perempuan atau adanya perbedaan dalam daya tahan tubuh anak laki-laki dan perempuan. Hal ini dihubungkan dengan kejadian bronkiolitis dan pneumonia akibat virus yang lebih banyak mengenai anak laki-laki. Hal ini sesuai dengan teori menurut Maryunani yang mengemukakan bahwa faktor risiko yang meningkatkan insiden pneumonia yaitu balita dengan jenis kelamin laki-laki (Centiany, 2013).

Pencegahan pneumonia dilaksanakan melalui upaya peningkatan kesehatan seperti imunisasi, perbaikan gizi dan perbaikan lingkungan pemukiman. Peningkatan pemerataan cakupan kualitas pelayanan kesehatan juga akan menekan morbiditas dan mortalitas pneumonia. Peranan masyarakat sangat menentukan keberhasilan upaya penanggulangan pneumonia. Terpenting adalah masyarakat memahami cara mendeteksi dini dan cara mendapatkan pertolongan pertama (care seeking) (Centiany, 2013).

Selain itu, upaya terus ditingkatkan guna menekan perkembangan penyakit ini. Badan Kesehatan Dunia (WHO) menetapkan target bahwa pada tahun 2025, angka kematian balita akibat pneumonia, dapat ditekan semaksimal mungkin.Salah satu program yang kian digencarkan guna mencapai tujuan ini adalah The Integrated Global Action Plan for the Prevention and Control of Pneumonia and Diarrhoea/Rencana Aksi Global Terpadu guna mencegah dan menangani pneumonia dan diare.

Diharapkan, program ini dapat mempercepat tercapainya pengendalian angka kejadian dan angka kematian akibat pneumonia dan diare pada balita di seputar dunia, antara lain tindakan pencegahan (kampanye pemberian ASI ekslusif selama 6 bulan, vaksinasi, dan sanitasi dalam kehidupan sehari-hari) dan tindakan penanganan dengan memastikan bahwa balita yang menderita pneumonia mendapatkan akses perawatan yang tepat agar dapat sembuh.

Mengingat masih tingginya angka kejadian pneumonia pada balita serta resiko tinggi angka kejadian pada rentang usia balita, maka sebaiknya perlu upaya peningkatan derajat kesehatan balita dengan memberikan ASI Eksklusif, perbaikan gizi sehat dan seimbang, serta kelengkapan pemberian imunisasi pada balita untuk meningkatkan daya tahan tubuh terhadap paparan risiko penyakit seperti kejadian penyakit pneumonia. Hal ini perlu upaya tenaga kesehatan untuk mendukung keberhasilan program pencegahan pneumonia pada balita disamping memberikan penyuluhan tentang pengenalan tanda dan gejala kejadian pneumonia, juga mendukung pemberian ASI Ekslusif, kelengkapan imunsiasi dan makanan yang bergizi bagi balita.

Dari hasil penelitian ditemukan bahwa dari 35 responden kasus sebanyak 16 responden $(45,7 \%)$ memiliki sosial ekonomi keluarga yang rendah dan 19 responden $(54,3 \%)$ memiliki sosial ekonomi keluarga
Puskesmas Tahtul Yaman Kota Jambi (Suryati, Natasha, N, Id'ys, N) yang tinggi. Sedangkan dari 35 responden kontrol sebanyak 30 responden $(85,7 \%)$ memiliki sosial ekonomi keluarga yang tinggi dan hanya 5 responden $(14,3 \%)$ memiliki sosial ekonomi keluarga yang rendah.

Hasil penelitian menggunakan uji analisis ChiSquare dengan tingkat kepercayaan 95\% $(\alpha=0,05)$ diperoleh p-value $(0,009)<\alpha(0,05)$, hal ini berarti adanya hubungan yang signifikan antara faktor sosial ekonomi keluarga dengan kejadian pneumonia pada balita di Wilayah Kerja Puskesmas Tahtul Yaman Kota Jambi peeriode tahun 2015.

Hasil penelitian di atas menunjukkan bahwa semakin tinggi ekonomi keluarga maka akan semakin kecil resiko kejadian pneumonia pada balita. Sebaliknya, semakin rendah ekonomi keluarga maka akan semakin besar resiko kejadian pneumonia pada balita. Hal ini juga diketahui dari nilai odds ratio $(\mathrm{OR})=5,053$, artinya balita dengan sosial ekonomi keluarga yang rendah berisiko mempunyai peluang kali untuk mengalami kejadian pneumonia dibandingkan dengan balita dengan sosial ekonomi keluarga yang tinggi.

Penelitian ini sejalan dengan penelitian Athena Anwar dan Ika Dharmayanti pada tahun 2014 dalam penelitian yang berjudul "Pneumonia Pada Anak Balita di Indonesia". Hasil menunjukkan bahwa faktor risiko yang paling berperan dalam kejadian pneumonia balita, salah satunya adalah tingkat ekonomi keluarga/kuintil indeks kepemilikan $(\mathrm{OR}=1,19 ; 95 \% \mathrm{CI}=1,10-1,30)$. Risiko pneumonia balita pada rumah tangga dengan tingkat ekonomi rendah (menengah dan terbawah) lebih tinggi dibandingkan dengan tingkat ekonomi tinggi (menengah atas sampai teratas) $(\mathrm{OR}=1,19)$. Hal ini dimungkinkan karena rumah tangga dengan status ekonomi yang lebih tinggi dapat memiliki kemampuan lebih baik dalam pemenuhan kebutuhannya, termasuk pemeliharaan kesehatan (meningkatkan akses terhadap pelayanan kesehatan dan ibu yang berpendidikan lebih tinggi diharapkan mempunyai informasi dan wawasan yang lebih baik termasuk dalam pemecahan masalah kesehatan.

Status ekonomi keluarga menggambarkan kekuatan keluarga untuk melangsungkan kehidupan sehari-hari.Status ekonomi keluarga juga berperan di dalam pengambilan keputusan bertindak terutama yang berkaitan dengan keuangan keluarga.Ekonomi keluarga dapat mempengaruhi kemampuan keluarga dalam pemenuhan kebutuhan baik itu kebutuhan pokok rumah tangga maupun kebutuhan sekunder lainnya termasuk pemenuhan kebutuhan akses pelayanan kesehatan.

Kelompok masyarakat yang berasal dari sosioekonomi rendah relatif lebih banyak mengunjungi fasilitas pelayanan medis. Penduduk yang berpenghasilan rendah berisiko sakit $43 \%$ dan terakses lebih banyak terhadap pelayanan kesehatan $9 \%$. Hal tersebut memperlihatkan pola hubungan monotonic yang mengindikasikan bahwahubungan yang terjadi tidak semata-mata disebabkan oleh masalah kemiskinan. Kontribusi kemiskinan pada kejadian pneumonia balita ditemukan sekitar 19,9\%. Apabila kemiskinan keluarga apat diatasi, maka prevelensi 
pneumonia balita akan dapat diturunkan dari 5,4\% menjadi 4,33\% . Ekonomi mempunyai pengaruh besar terhadap kesehatan karena kemampuan ekonomi merupakan sumber daya yang penting dalam peningkatan kesehata. Seperti halnya dalam kepemilikan rumah sehat, seseorang yang ingin membangun suatu rumah tentunya akan mengukur tingkatkemampuan ekonominya, terutama menyangkut kesiapan finansial. Pembangunan rumah dengan memikirkan kriteria rumah sehat juga akan berpengaruh pada kemampuan ekonominya dalam pengadaan dana untuk membangun rumah sesuai kriteria tersebut (Manurung, 2013).

Selain itu, dalam hal pemenuhan kebutuhan pokok terutama pengadaan makanan bergizi serta perawatan kesehatan balita, kemampuan ekonomi juga akan turut mempengaruhi dalam hal kebutuhan pangan bergizi. Keterbatasan penghasilan keluarga turut menentukan mutu makanan yang disajikan. Tidak dapat disangkal bahwa penghasilan keluarga akan turut menentukan hidangan yang disajikan untuk keluarga sehari-hari, baik kualitas maupun jumlah makanan. Mengingat besarnya dampak ekonomi keluarga terhadap risiko kejadian pneumonia pada balita, maka sebaiknya keluarga meskipun dengan keterbatasan ekonomi tetap mengupayakan kondisi lingkungan fisik rumah yang sehat meskipun hanya berbentuk rumah sederhana serta meningkatkan keasrian di sekitar lingkungan rumah. Disamping itu, perlunya penataan pengeluaran rumah tangga dengan memperioritaskan kebutuhan seperti kebutuhan pangan dan kesehatan anggota keluarga sebagai prioritas utama dalam pengeluaran rumah tangga (Manurung, 2013).

Pendapatan keluarga yang tinggi akan dapat mendukung untuk melakukan upaya pencegahan terhadap kejadian pneumonia pada balita. Dengan adanya pendapatan keluarga yang tinggi maka akan semakin besar pula alokasi pendanaan yang disediakan untuk peningkatan kesehatan bagi keluarganya seperti penyediaan makanan yang mengandung gizi lengkap, biaya pengobatan jika ada gejala dan tanda-tanda dari penyakit dapat langsung memeriksakan diri dengan segera dengan didukung adanya biaya. Selain itu, kemampuan ekonomi yang didukung pendapatan keluarga yang tinggi akan mampu menyediakan tempat tinggal yang layak huni yang memenuhi syarat rumah sehat.

\section{Kesimpulan}

Berdasarkan hasil penelitian dan uraian dalam pembahasan tentang hubungan faktor lingkungan fisik dan sosial ekonomi keluarga dengan kejadian pneumonia pada balita di Wilayah Kerja Puskesmas Tahtul Yaman Kota Jambi, maka dapat diambil beberapa kesimpulan sebagai berikut:

1. Penderita pneumonia sebagian besar berumur 12-23 bulan $(57,1 \%)$ dan sebagian besar berjenis kelamin laki-laki sebanyak $(74,3 \%)$.

2. Penderita pneumonia sebagian besar memiliki lingkungan fisik yang kurang baik sebanyak
Puskesmas Tahtul Yaman Kota Jambi (Suryati, Natasha, N, Id'ys, N)

$(68,6 \%)$ responden dan sebagian lainnya memiliki lingkungan fisik yang baik sebanyak $(31,4 \%)$ responden.

3. Penderita pneumonia sebagian besar memiliki sosial ekonomi keluarga yang tinggi sebanyak $(54,3 \%)$ responden dan sebagian lainnya memiliki sosial ekonomi keluarga yang rendah sebanyak $(45,7 \%)$ responden.

4. Terdapat hubungan antara faktor lingkungan fisik dengan kejadian pneumonia pada balita, dengan $\mathrm{p}$-value $=0,017$ dan $\mathrm{OR}=3,692$.

5. Terdapat hubungan antara faktor sosial ekonomi keluarga dengan kejadian pneumonia pada balita, dengan $\mathrm{p}$-value $=0,009$ dan $\mathrm{OR}=5,053$.

\section{Daftar Pustaka}

Gupta, L.C. dan Thawari, S. (2016). Plumbing System in High Rise Building. International Journal for Innovative Research in Science \& Technology,2(11), 719-723.

Noerbambang, M.S. dan Morimura, T. (1984). Perancangan dan Pemeliharaan Sistem Plambing. Jakarta: Pradnya Paramita.

Putra, D.A., dkk. 2015. Perencanaan Sistem Instalasi Plambing Air Bersih Gedung Park View Hotel. Jurnal Reka Lingkungan, 3 (2) : 1-11.

Ramachandran. (2016). Nuances of Plumbing in High Rise Buildings. International Journal of Research in Engineering and Technology,5(20), 20-15.

Standar Nasional Indonesia (SNI) 03-7065-2005. (2005). Tata Cara Perencanaan Sistem Plambing. Jakarta : Badan Standarisasi Nasional.

Tukiman, dkk. (2013). Perhitungan dan Pemilihan Pompa pada Instalasi Pengolahan Air Bebas Mineral Iradiator Gamma Kapasitas 200 Kci. Prosiding Pertemuan Ilmiah Perekayasaan Perangkat Nuklir PRPN - BATAN.

World Health Organization. (2006). Health Aspects of Plumbing.

Adnani. (2011). Buku Ajar Ilmu Kesehatan Masyarakat. Yogyakarta: Nuha Medika.

Aji. (2008). Faktor - Faktor Lingkungan Fisik Rumah yang Berhubungan dengan Kejadian Pneumonia pada Anak Balita di Wilayah Kerja Puskesmas Kawunganten Kabupaten Cilacap.

Arsindo. GSB - Garis Sempadan Bangunan. Terdapat dalam http://www.arsindo.com. 2014

Centiany. (2013). Hubungan antara Faktor Lingkungan Fisik Rumah dengan Kejadian Infeksi Saluran Pernapasan (ISPA) pada Balita di Kelurahan Malalayang 1 Kota Manad.

Dinas Kesehatan Kota Jambi. (2015). Jumlah Balita Menderita Pneumonia Pada Tahun 2015.

Dinas Kesehatan Provinsi Jambi. (2014). Jumlah Balita Menderita Pneumonia Pada Tahun 2014.

Disnaketrans Provinsi Jambi. (2016). Surat Keputusan Gubernur No. 458 tentang UMP Jambi Tahun 2016.

Kemenkes RI. (2012). Pneumonia Balita. Jendela Epideomologi. ISSN 2087-1546.

Manurung. (2013). Gangguan Sistem Pernafasan Akibat Infeksi. Jakarta; Trans Info Media.

Maryunani. (2010). Ilmu Kesehatan Anak Dalam Kebidanan. Jakarta: TIM

Pudiastuti. (2011). Waspadai Penyakit Pada Anak. Jakarta: PT Indeks.

Putriani. Faktor Risiko Lingkungan yang berhubungan dengan Kejadian Pneumonia pada Balita di Wilayah 
Hubungan Faktor Lingkungan Fisik Dan Sosial Ekonomi Keluarga Terhadap Kejadian Pneumonia Pada Balita Di Wilayah Kerja Puskesmas Tahtul Yaman Kota Jambi (Suryati, Natasha, N, Id'ys, N)

Kerja UPTD Puskesmas Kecamatan Pontianak Selatan 2014. Vol 1 No 1

Roestanto. Perencanaan Pembangunan Kawasan Industri.

Dipetik pada tahun 2014 dari http://www.definisi-

pengertian.com
Wijayaningsih. (2013). Asuhan Keperawatan Anak. Jakarta: Trans Info Media. 